\title{
ARTICLES
}

\section{A STUDY TO ASSESS THE LEVEL OF FEEDING PERFORMANCE AMONG PRETERM BABIES IN GOVERNMENT HOSPITAL IN KUZHITHURAI, TAMIL NADU}

\author{
Mrs. B.S. Shali
}

Associate Professor, Mamata College of Nursing, Khammam, Telangana, India. DOI: http://doi.org/10.47211/tg.2020.v07i03.011

\begin{abstract}
Introduction: Preterm birth also known as premature birth is the birth of a baby at less than 37 weeks of gestation. Preterm babies are not fully prepared to live in the world outside their mother's womb. When babies are born prematurely, their digestive systems may not be fully developed. As a result, many of these small infants experience feeding difficulties such as problems establishing nipple feedings at breast or with the bottle. Methodology: Descriptive research approach was adopted using descriptive research design. The sample consisted of 30 preterm babies with poor feeding performance. The samples were collected by using the non -probability convenient sampling technique. The level of feeding performance was assessed with the help of modified early feeding skill assessment scale for preterm babies. Results: Majority of 15 (50\%) preterm babies had poor feeding performance, 12 (40\%) preterm babies had average feeding performance and 3 (10\%) had good feeding performance. It was not possible to compute chi-square test to find out the association between level of feeding performance and their socio-demographic variables, as the expected values are less than 5. Conclusion: The overall study clearly showed that there were poor and average feeding performances of preterm babies.
\end{abstract}

Key Words: Preterm babies, level of feeding, government hospital.

\section{ABOUT AUTHOR:}

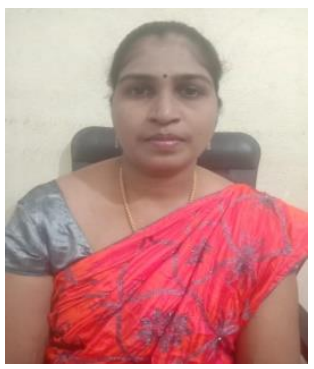

Mrs. B. S. Shali is Associate Professor at Mamata College of Nursing, Khammam, Telanagana, India. She has published paper in various National and International Journals and Organized various workshops and conferences. She is doing Ph.D in Himalayan University, Itanagar, Arunachal Pradesh, India. 


\section{ARTICLES}

\section{INTRODUCTION}

"Every child comes with the message that God is not yet discouraged of man."

\section{- $\quad$ Rabindranath Tagore}

Preterm birth is also known as premature birth. It is the birth of a baby at less than 37 weeks of gestation. Preterm babies are not fully prepared to live in the world outside their mother's womb. Premature babies especially those born very early often have complicated medical problems.

When babies are born prematurely, their digestive systems may not be fully developed. As a result, many of these small infants experience feeding difficulties such as problems establishing nipple feedings at breast or with the bottle. This may occur because the infants cannot suck and swallow properly. Gastric residuals occur when babies cannot completely empty their stomach from a previous feeding.

\section{STATEMENT OF THE PROBLEM}

'A study to assess the level of feeding performance among preterm babies in Government hospital, Kuzhithurai in Tamil Nadu'

\section{OBJECTIVES OF THE STUDY}

The objectives of the study are -

- To describe the mother and child related socio-demographic variables.

- To assess the level of feeding performance among preterm babies

- To find out the association between the level of feeding performance with their selected mother and child related variables.

\section{MATERIALS AND METHODS}

Research Approach: Descriptive research approach

Research Design: Descriptive research design

Setting of the Study: The study was conducted in Government hospital, Kuzhithurai in Tamil Nadu.

Sample: Sample comprised of preterm babies with poor feeding performance in Government hospital, Kuzhithurai

Sampling Technique: Non-probability convenience sampling technique

Sample Size: The sample size for the study comprises of 30 preterm babies who fulfilled the inclusion criteria.

Criteria for Sample Selection: -

Inclusion criteria

The study included those preterm babies -

- who were available at the time of data collection.

- who were with poor sucking reflex.

\section{Exclusion criteria}

The study excluded those preterm babies -

- who were with congenital anomalies.

- whose parents were not willing to participate in the study.

Description of the Tool

The researcher had used the following tools for data collection -

Tool - I: Mother and Child related Variable Proforma

The tool consisted of 12 items for obtaining information about mother and child related variables.

Tool - II: Modified Early Feeding Skill Assessment Scale for Preterm Babies

- Modified early feeding skill assessment scale for preterm babies was used individually to collect the data with regard to feeding performance.

\section{Scoring Procedures}

- Modified early feeding skill assessment scale for preterm infants consisted of 33 numerically scaled, 0-33 scores. The total maximum and minimum scores were 33 and 0 respectively. The score on the numerical scale, 0 and 33 was interpreted as -

\begin{tabular}{|c|c|l|}
\hline SI. No. & Score & Interpretation \\
\hline 1. & $0-11$ & Poor sucking skill \\
\hline 2. & $12-22$ & Average sucking skill \\
\hline 3. & $23-33$ & Good sucking skill \\
\hline
\end{tabular}




\section{ARTICLES}

Content Validity: The content validity of the tool was established on the basis of opinions of experts from nursing departments. Suggestions from experts were incorporated in the tool and the approved tool was used for data collection.

\section{Data Collection Procedure}

The data collection was done for a period of one month. Initial permission was obtained from the research ethical committee. Formal permission was obtained from higher authorities of the Government hospital, Kuzhithurai. At first, a rapport was established and the purpose of the study was explained to parents and staff nurses who worked in NICU. The sample of 30 preterm babies was selected using Non-probability convenient sampling technique. Data were collected by using Mother and Child related variable Proforma and Modified Early Feeding Skill Assessment Scale for Preterm Babies. The researcher conducted the assessment with the help of modified early feeding skill assessment scale. Towards the end, the researcher thanked the NICU staff and mothers of preterm babies for their co-operation.

\section{DATA ANALYSIS AND INTERPRETATION}

Table - 1: Data pertaining to frequency and percentage distribution of selected mother related variables $\mathbf{N}=\mathbf{3 0}$

\begin{tabular}{|c|c|c|c|}
\hline SI. No. & Mother related Variables & $\begin{array}{c}\text { Frequency } \\
\mathbf{f}\end{array}$ & $\begin{array}{c}\text { Percentage } \\
\%\end{array}$ \\
\hline 1. & $\begin{array}{l}\text { Mother's age } \\
\text { a. } \quad<20 \text { years } \\
\text { b. } 21-30 \text { years } \\
\text { c. }>35 \text { years }\end{array}$ & $\begin{array}{r}0 \\
25 \\
5\end{array}$ & $\begin{array}{c}0 \\
84.00 \\
16.00\end{array}$ \\
\hline 2. & $\begin{array}{l}\text { Mother's education } \\
\text { a. Profession } \\
\text { b. Graduate or Post graduate } \\
\text { c. Intermediate } \\
\text { d. Higher secondary school } \\
\text { e. Middle school }\end{array}$ & $\begin{array}{r}2 \\
3 \\
15 \\
8 \\
2\end{array}$ & $\begin{array}{r}6.66 \\
10.00 \\
50.00 \\
26.60 \\
6.66\end{array}$ \\
\hline 3. & $\begin{array}{l}\text { Family monthly income } \\
\text { a. } \geq 25000 \\
\text { b. } 20000-24999 \\
\text { c. } 15000-19999 \\
\text { d. } 10000-14999 \\
\text { e. } 5000-9999\end{array}$ & $\begin{array}{r}2 \\
3 \\
10 \\
13 \\
2\end{array}$ & $\begin{array}{r}6.66 \\
10.00 \\
33.33 \\
43.30 \\
6.66 \\
\end{array}$ \\
\hline 4. & $\begin{array}{l}\text { Place of delivery } \\
\text { a. Government hospital } \\
\text { b. Private hospital } \\
\text { c. Home }\end{array}$ & $\begin{array}{r}6 \\
24 \\
0\end{array}$ & $\begin{array}{l}20.00 \\
80.00 \\
0\end{array}$ \\
\hline 5. & $\begin{array}{l}\text { Mode of delivery } \\
\text { a. LSCS } \\
\text { b. Normal }\end{array}$ & $\begin{array}{r}22 \\
8\end{array}$ & $\begin{array}{l}73.30 \\
26.60\end{array}$ \\
\hline 6. & $\begin{array}{l}\text { Birth order } \\
\text { a. First } \\
\text { b. Second and third } \\
\text { c. Fourth and above }\end{array}$ & $\begin{array}{r}16 \\
14 \\
0\end{array}$ & $\begin{array}{c}53.30 \\
46.60 \\
0\end{array}$ \\
\hline 7. & $\begin{array}{l}\text { Place of residence } \\
\text { a. Urban } \\
\text { b. Rural }\end{array}$ & $\begin{array}{r}26 \\
4\end{array}$ & $\begin{array}{l}86.60 \\
13.30 \\
\end{array}$ \\
\hline
\end{tabular}

The above table represents the frequency and percentage distribution of selected mother related variables of preterm babies with regard to mother's age, mother's education, family monthly income, place of delivery, mode of delivery, birth order and place of residence.

With regard to age, majority of $25(83.3 \%)$ mothers were found between the age group of 21-30 years, and 5 $(16.6 \%)$ were in the age group of $>35$ years. 


\section{ARTICLES}

With regard to mothers' education, majority of $15(50 \%)$ mothers had completed intermediate or high school education, $8(26.6 \%)$ completed higher secondary education, $3(10 \%)$ had obtained graduation or post graduate education and remaining $2(6.66 \%)$ mothers had undertook both middle school education and professional courses.

With regard to family monthly income, majority 13 (43.3\%) of the mothers were earning an income between Rs.10000-14999; 10 (33.33\%) of the mothers were earning an income between Rs.15000-19999 and 3 (10\%) were earning between Rs.20000-24999. On the lower side, 2 (6.66\%) mothers were earning an income between Rs.5000-9999 and another 2 mothers were earning more than Rs.25000.

With regard to place of delivery, majority of $24(80 \%)$ mothers had their delivery in private hospitals and the remaining $6(20 \%)$ in government hospital.

With regard to mode of delivery, majority of $22(73.33 \%)$ mothers were delivered through LSCS and fewer mothers i.e. $8(26.6 \%)$ of them were delivered through normal vaginal delivery.

With regard to the birth order, majority of $16(53.3 \%)$ mothers had their first child, and the remaining 14 (46.6\%) mothers had their second and third child.

With regard to place of residence, majority of $26(86.6 \%)$ mothers were from urban background and remaining 4 (13.3\%) were from rural background.

Table - 2: Data pertaining to frequency and percentage distribution of selected child related variables.

\begin{tabular}{|c|c|c|c|}
\hline \multicolumn{4}{|c|}{$\mathrm{N}=\mathbf{3 0}$} \\
\hline SI. No. & Child related variables & $\begin{array}{l}\text { Frequency } \\
\text { (f) }\end{array}$ & $\begin{array}{c}\text { Percentage } \\
\text { (\%) }\end{array}$ \\
\hline 1. & $\begin{array}{l}\text { Gestational weeks at birth } \\
\text { a. } 31-36 \text { weeks } \\
\text { b. } 26-30 \text { weeks } \\
\text { c. }<26 \text { weeks }\end{array}$ & $\begin{array}{r}23 \\
7 \\
0\end{array}$ & $\begin{array}{c}76.60 \\
23.30 \\
0\end{array}$ \\
\hline 2. & $\begin{array}{l}\text { Birth weight of infant } \\
\text { a. } \quad<2 \mathrm{~kg} \\
\text { b. } \quad 2-3 \mathrm{~kg} \\
\text { c. } \quad>3 \mathrm{~kg}\end{array}$ & $\begin{array}{r}11 \\
17 \\
2\end{array}$ & $\begin{array}{r}36.60 \\
56.60 \\
6.66\end{array}$ \\
\hline 3. & $\begin{array}{l}\text { Sex of the baby } \\
\text { a. Male } \\
\text { b. Female }\end{array}$ & $\begin{array}{l}18 \\
12 \\
\end{array}$ & $\begin{array}{l}60.00 \\
40.00 \\
\end{array}$ \\
\hline 4. & $\begin{array}{l}\text { Low birth weight } \\
\text { a. Yes } \\
\text { b. No }\end{array}$ & $\begin{array}{l}18 \\
12\end{array}$ & $\begin{array}{l}60.00 \\
40.00\end{array}$ \\
\hline 5. & $\begin{array}{l}\text { Whether preterm } \\
\text { a. Yes } \\
\text { b. No }\end{array}$ & $\begin{array}{r}30 \\
0 \\
\end{array}$ & $\begin{array}{c}100.00 \\
0 \\
\end{array}$ \\
\hline
\end{tabular}

The above table represents the frequency and percentage distribution of selected child related variables which includes gestational age, birth weight, sex of the baby, low birth weight and whether or not preterm.

With regard to gestational weeks at birth, majority of 23 (76.6\%) babies were delivered during 31-36 weeks of gestation, and remaining 7 (23.33\%) babies were delivered between 26-30 weeks of gestation.

With regard to birth weight of the child, majority of 17 (56.6\%) babies weighed between 2-3 kg, 11 (36.6\%) babies had birth weight of more than $2 \mathrm{~kg}$ and the remaining $2(6.66 \%)$ had birth weight of more than $3 \mathrm{~kg}$.

With regard to sex of the baby, majority of $18(60 \%)$ babies were males and the remaining $12(40 \%)$ were females.

With regard to low birth weight, majority of $18(60 \%)$ preterm babies had low birth weight and the remaining 12 (40\%) had normal birth weight.

With regard to preterm delivery, majority of $30(100 \%)$ babies delivered before 37 weeks of gestation. 


\section{ARTICLES}

Table - 3: Data pertaining to frequency and percentage distribution of levels of feeding performance among preterm babies.

\begin{tabular}{|c|c|c|c|}
\hline \multirow{2}{*}{ Levels of feeding performance } & \multirow{2}{*}{ Score } & \multicolumn{2}{|c|}{ Number of samples } \\
\hline & & f & $\%$ \\
\hline Poor & $0-11$ & 15 & 50 \\
\hline Average & $12-22$ & 12 & 40 \\
\hline Good & $23-33$ & 3 & 10 \\
\hline
\end{tabular}

Table - 3 shows the frequency and percentage distribution of levels of feeding performance among preterm babies. It shows, majority of 15 (50\%) preterm babies had poor feeding performance, 12 (40\%) had Average feeding performance and $3(10 \%)$ had good feeding performance.

It was not possible to compute chi-square test to find out the association between levels of feeding performance and their socio-demographic variables, as the expected values were less than 5 .

\section{MAJOR FINDINGS OF THE STUDY}

- With regard to age, majority of 25 (83.3\%) mothers were found between the age group of 21-30 years

- With regard to mothers' education, majority of 15 (50\%) mothers had completed intermediate or high school education,

- With regard to family monthly income, majority of 13 (43.3\%) mothers were earning an income between Rs.10000-14999.

- With regard to place of delivery, majority of $24(80 \%)$ mothers had their delivery in a private hospital.

- With regard to mode of delivery, majority of 22 (73.33\%) mothers were delivered through LSCS.

- With regard to the birth order, majority of $16(53.3 \%)$ mothers delivered their first child.

- With regard to place of residence, majority of 26 (86.6\%) mothers were from urban background.

- With regard to birth weight of the child, majority of 17 (56.6\%) babies weighed between 2-3 kg.

- With regard to sex of the baby, majority of 18 (60\%) babies were males.

- With regard to low birth weight, majority of $18(60 \%)$ preterm babies had low birth weight.

- With regard to preterm delivery, majority of 30 (100\%) babies were delivered before 37 weeks of gestation.

- $15(50 \%)$ preterm babies were found to have poor feeding performance

- $12(40 \%)$ had average feeding performance

- $3(10 \%)$ had good feeding performance.

\section{RECOMMENDATIONS}

- A similar study may be conducted with longer time and extended days which may yield more reliable results.

- The similar study can be conducted by selecting a larger sample on a long-term basis.

- The study can be conducted in different settings with similar facilities.

- A comparative study can be conducted with control and experimental groups. 


\section{ARTICLES}

\section{REFERENCES}

\section{Books}

1. Achar's (2014) Text Book of Paediatrics 3rd edition Chennai, Orient Long Man Publishers

2. Assuma Beevi T.M., (2010) A Text Book of Paediatrics Nursing 1st edition New Delhi Elsevier Publisher

3. Ball, Bindler, (2009) Principles of Paediatric Nursing: Caring for Children 4th edition Pearson Publisher

4. Dorothy RM, 2006 Text Book of Paediatric Nursing 6th edition New Delhi Elsevier Publications

5. Kantasagar, Paediatric Nursing 2nd edition New Delhi A.P. Jain and Co publishers.

6. L C Gupta, Abhitabh Gupta, (2002) Manual of First Aid, Jaypee Brothers, New Delhi

7. Manoj Yadav, (2011) A Text Book of Child Health Nursing, PV Books, New Delhi

8. Wong's Essentials Of Paediatric Nursing, (2005) 7th edition, Elsevier Publisher, New Delhi

9. Ghai, O.P., Piyush Gupta.,\& Paul, V.K. (2005). Essential Paediatric Nursing, CBS publishers. Page Number 155. Journals

10. K Mizuno, A Ueda. "Maturation of sucking reflex in preterm babies"- The Journal of paediatrics, August 2003.

11. J Callen, J Pinelli. "Incidence of preterm delivery" journal of Advances in Neonatal Care, June 2005.

12. C Lau, HR Sheena, RJ Shulman, RJ Schanler. "Oral feeding in low birth weight infants," The Journal of paediatrics, 1997.

13. SM Thoyre, CS Shaker, KF Pridham. "Early feeding skill assessment scale for preterm infants." The journal of paediatric nursing, August 2008.

14. Yea-shwu Hwang. "Effects of pre- feeding oral stimulation on feeding performance of preterm infants," The Journal of Paediatrics, Volume 77, August 2019, pages 869-873. 